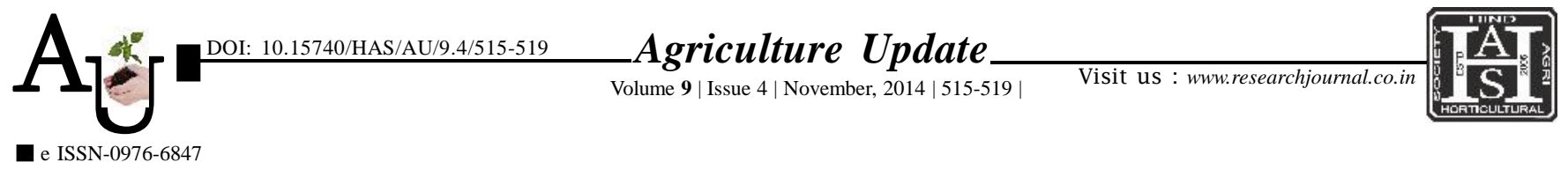

\title{
Research Article Extent of use of soil and water resources by the farm families of Bijapur and Chitradurga districts of Karnataka
}

\section{Received :}

19.08.2014;

Revised :

16.09.2014;

Accepted :

28.09.2014

\section{KEY WoRds:}

Soil, Water, Land holding, Vegetation, Livestock

\section{ANIL BIRADAR, S.S. DOLLI, SHREESHAIL RUDRAPUR AND MITHUN P. KUDACHI}

SUMMARY : The study conducted revealed that, the average land holding of small, medium and large farmers of Bijapur district was 3.36 acre, 7.88 acre and 14.76 acre, respectively and in case of Chitradurga district average land holding of small, medium and large farmers was 2.56 acre, 7.86 acre and 13.68 acre, respectively. With respect to soil type and extent, most of the small farmers $(97.61 \%)$ possessed black soil, followed by large farmers $(79.5 \%)$ and medium farmers $(76.39 \%)$ in Bijapur district. With respect to soil type and extent in Chitradurga district, all most all farmers were having red soil. With respect to vegetation resource is considered in Bijapur district, small famers possessed higher number of fruit and forest trees per acre (0.80 and 2.66), where medium and large farmers had almost same number of fruit trees $(0.25$ and $0.22 / \mathrm{ac})$, however, with respect to forest trees, large farmers had relatively more forest trees $(1.42 / \mathrm{ac})$ than medium farmers $(0.97 / \mathrm{ac})$ and the same was observed in Chitradurga district also. The livestock component is concerned, small farmers had higher number of livestock per acre (0.57) followed by medium (0.39) and large farmers (0.31). In case of Chitradurga district, small farmers had higher number of livestock $(0.72 / \mathrm{ac})$ followed by medium $(0.20)$ and large farmers (0.15). The source of water for irrigation was open well as well as borewell in Bijapur district. While, in case of Chitradurga district, only borewell was the source of water for irrigation. The number of open wells and borewells in Bijapur district were found higher among large farmers i.e. 50 per cent of large farmers had open wells and 62.50 per cent had borewells, followed by medium farmers (58\% of wells and $38.50 \%$ of borewell) and small farmers (33.33\% of wells and $8.33 \%$ of borewell), whereas, the number of borewells in Chitradurga district was found higher among large farmers $(91.67 \%)$, followed by medium farmers $(78 \%)$ and small farmers $(8.33 \%)$.

How to cite this article : Biradar, Anil, Dolli, S.S., Rudrapur, Shreeshail and Kudachi, Mithun P. (2014).Extent of use of soil and water resources by the farm families of Bijapur and Chitradurga districts of Karnataka. Agric. Update, 9(4): $515-519$.

Author for correspondence :

\section{SHREESHAIL \\ RUDRAPUR \\ Department of \\ Agricultural Economics, College of Agriculture, \\ University of Agricultural Sciences, DHARWAD (KARNATAKA) INDIA \\ Email: shree4476@ gmail.com}

See end of the article for authors' affiliations 